\title{
MARKET AND TRADE OF ORGANIC FRUITS IN SERBIA
}

\author{
Radivoj Prodanović', Boris Kuzman', David Jovović3 ${ }^{3}$ Lazar Ozegović ${ }^{4}$
}

\begin{abstract}
The aim of paper is to investigate the market and traffic flows of organic fruit, respectively factors that determine demand, customer attitudes and their motives for purchase.

From methods that are applied, the key methods are questionnaire and interview, and statistical, graphical and logical methods are used.

Organic fruits market has begun to be developed in recent years, there is a demand, but on a small scale. Sustainability and further development of organic fruit production is largely caused by demand.

Employed woman, with good financial condition, with children, higher or high educated, ages between 30 and 50 years, with a place of residence in the city, buys organic fruits.

Health safety, quality, production area and care for the environment are the most important motives for purchase of organic fruits. Certificate, recommendations, appearance and taste of product, curiosity and packaging have secondary importance.

The key factors, because of which the customers do not buy organic fruits, are unavailability in sales channels, high price, lack of confidence in organic products and low incomes.
\end{abstract}

Key words: market, traffic, demand, organic fruits, Serbia.

JEL: Q13, A11, M31

\section{Introduction}

Organic fruits are produced in a system which excludes the use of inputs such as: fertilizers,

1 Radivoj Prodanovic Ph.D., Assistant Professor, University Business Academy in Novi Sad, Faculty of Economics and Engineering Management in Novi Sad, Cvecarska Street no. 2, 21000 Novi Sad, Serbia, Phone: +381 21400 484, E-mail: rprodanovic@fimek.edu.rs

2 Boris Kuzman, Ph.D., Associate Professor, Institute of Agricultural Economics, Volgina Street no. 15, 11060 Belgrade, Serbia, Phone: +381 63590 129, E-mail: kuzmanboris@yahoo.com

3 David Jovović Ph.D., Associate Professor, University of Prishtina, Faculty of Agriculture, 38219 Lešak, Telephone: +381 2888 261, E-mail: david.jovovic@pr.ac.rs

4 Lazar Ozegovic Ph.D., Associate Professor, University Business Academy in Novi Sad, Faculty of Economics and Engineering Management in Novi Sad, Cvecarska Street no. 2, 21000 Novi Sad, Serbia, Phone: +381 21400 484, E-mail: ozegovic.lazar@gmail.com

EP 2017 (64) 1 (141-155) 
pesticides, growth hormones, genetically modified organisms. The certificate guarantees high quality and health safety of organic fruits.

Organic fruits market is developing, thanks to increased demand, which is the result of increased concern for health and environmental quality. The share of organic fruits in the total offer of food is relatively small, while it presents significant segment in the total offer of organic food. The organic fruits market is interesting for potential participants, because of existing insufficient offer and lower level of competition.

Offer and demand of organic fruits are out of balance. Demand is greater than offer, so it seems significant to explore which factors dominantly influence on traffic flows and behaviour of customers, in order to exploit the evident market potential.

\section{The Aim and Significance of Paper}

The aim of paper is to research the market and traffic flows of organic fruits, in respectively factors that determine demand, customers' attitudes and their motives for purchase. The purpose of the research is to determine the absorptive power of the market for organic fruits, in order to estimate the impact on the further development of organic fruit production.

Considering that modern trend in the nutrition sets the new requirements for quality and health safety of food, the research, which is aimed to make overview of traffic flows of organic fruits, can be considered as significant.

\section{Methodology}

We used surveys, interviews, statistical and logical methods.Among the other standard methods, there is application of the methods of description, deductive and inductive methods, analysis and synthesis, generalization and abstraction.

The questionnaire presents the combination of simple and selected sample. The questionnaire is designed to contain mostly "closed questions" with the choice, with regard that respondents can give their own answer on some questions. The first part of the questionnaire presents questions about attitudes of customers about organic fruits and motives for purchase, while the second part presents general questions, such as age, gender, occupation, etc.Greater part of questionnaires is distributed in Novi Sad, and the rest is in places as Belgrade, Subotica etc. The survey has been being conducted from January to June 2016, and 317 questionnaires enter into processing. In data processing it is used software IBM SPSS Statistics 21, and the results are showed graphically.

\section{Results and Discussion}

\section{The Global Market of Organic Fruits}

The global market of organic food, especially organic fruits, is stable and is in increase despite financial crisis. The market's growth of organic food is limited due to insufficient production and offer, so that there is significant market potential, which can be utilized by new participants (Mitic, Gligorijevic, 2012). 
Market of organic fruits and vegetables is the fastest increasing sector of the food market with extremly high rates of growth, leading to supplying the market in various regions. As the insurance of sufficient quantities of organic food becomes a major concern, so commercial enterprises from developed countries are engaged in investing into developing countries, in order to fulfill the demand for these products (Sudarevic, 2007).

Organic fruits are bought by customers with relatively high purchasing power, but also the others who realized that food has a preventive impact on health protection, regardless of their weaker economic position. Economic developed countires have greater social product and they are potentially interesting market for producers of organic fruit (Prodanovic, 2015).

The organic fruit market firstly began to develop in the EU countries and the USA. The first impulses for development of this market have started off from offer side, where the farmers have been deciding to start with organic production, with the desire to reduce the use of chemicals or, however, from personal conviction, and just later because of the support that was being provided by the government of some states. The demand has also influenced on the development of organic food market, because the customers have showed interest for health food safety (Carolyn, Oberholtzer, 2009).

It is estimated that the global market for organic food products in 2014 amounted to 80 milliard dollars, of which share of fruits and vegetables is $45 \%$ (Willer, Lernoud, 2016). The world market and traffic of organic fruit record the trend of steady growth, by virtue of demand that is being increasing. In developed countries, organic fruits traffic has reached 4 to $5 \%$ (Milenkovic et al., 2011).

The organic fruits market and products are rapidly developing in several EU countries, which can be an interesting opportunity for exporters from developing countries (Matovic, Begovic, 2011).

Considering that Serbia records good results in exporting fruits to the EU, especially when it comes to exports of frozen raspberries and other berries, organic production and export of these products will provide even greater economic effects. The relative comparative advantage in exporting fruits from Serbia, which is being held at the maximum level, sholud be utilized and kept by production and offer of organic fruits (Kuzman et al., 2016).

According to Richter and Padel (2005), there are three basic levels of development od the organic food products market:

- $\quad$ Saturated market,

- $\quad$ Growing market

- Creating market.

The majority of markets in Western Europe are in the growth phase or maturity, and basic offer or organic items is available in almost every supermarket. The markets of Central and Eastern Europe, as well as those in other countries which are on lower level of development in the phase of formation. The demand growth for organic fruits in the world market is an 
opportunity for producers in developing countries.

Growth rates in the saturated markets amount to $5 \%$, and the volume of organic products sales is decreasing. The role of supermarkets is valuable in these markets. Growing markets have growth rates from 5 to $15 \%$, and traffic is dominantly being occured through specialized stores and direct sales. Creating markets are rapidly growing, represent niche marketing, they are pioneers in traffic and have lack of organizational structure. It includes specialized stores and direct sales. The organic fruits market in its entirety is an example of creataing market. In order to develop this market, it is necessary to conduct series of activities, where the marketing has a major role (Richter, Padel, 2005).

\section{The Organic Fruits Market in Serbia}

In the Republic of Serbia, and in neighboring countires, the development of organic food market is not satisfactory due to disorganised production, poor promotion, insufficient presence in the media. The key task is to connect all local actors in a cooperative chain and creating institutonal conditions for faster development of organic agriculture (Rakic, Rakic, 2009).

Reliable data about production and traffic of organic fruits are not available because the statistics does not separate specially organic from conventional products.

The organic fruits market in Serbia has begun to develop in recent years. The development of organic fruits market is contributed by the adoption of the Law on organic production and the introduction of a national character, which gives the confidence to customers and guarantees that the product is from strictly controlled production. The poor organization of market, problems in distribution and lack of information to customers are evident (Prodanovic, 2015).

Organic fruits can be bought in specialized store of "healthy food", on the shelves of some supermarkets, directly at the producers, via the Internet and at the stalls of some markets. The prices that some producers of organic fruits accomplish are greater for about 10-20\%, which is not enough for adequate valorization of their production (Marz et al., 2013). Organic fruits and products on Serbian market are from domestic production, and one part of it is imported. The largest part of organic fruit is exported, esspecially in the EU, because the domestic market is underdeveloped, due to lack purchasing power of the population (Berenji et al., 2013).

Organic fruits are distributed to the wholesale trade, supermarkets, specialized stores retail. Larger quantities of organic fruits are redeemed by processors. Supermarkets appearance has led to increasing prices of food, and at the same time decreasing producers' price. Producers generally can not achieve significantly higher prices of organic fruits, because of sales mediators in traffic who take high margin. Although the organic fruits have entered in the supermarket offer, it is not so much done on promotion. Practically, it is left to the customer to recognize organic productions and to decide by himself about possible purchase. Sales via the Internet (e-commerce) is far more advanced in developed countries, and this was of sale has also been started to develop in our country (Bio pantry and Eco label). 
The demand for organic fruits exists and is elastic, meaning that it is being changing with changes of price and incomes. Although the per capita income in Serbia has been decreased in Serbia in last decade, the demand for organic products is still limited because of food price growth (Marz et al., 2013).

The main obstacles of further development of domestic market of organic products are (Kalentic et al., 2014):

- $\quad$ Low purchasing power

- $\quad$ Lack of information to the customers

- Low ecological awareness

- $\quad$ Small volume of production

- Inappropriate labeled products (fruits mainly does not have label "organic product")

- $\quad$ Signs so-called "healthy food" often confuses customers ("green apple" and the like)

- $\quad$ In so-called "healthy food"stores, conventional product are also sold, what refuses potential customers of organic food

- Insufficient research of foreign markets in which it is desirable to perform (level of incomes, preferences, market segments, etc).

For development of organic fruit market it is needed to direct marketing strategy to target groups, such as the youth and all those who prefer healthy lifestyle. It sholud emphasize the advantages which organic fruits provide, such as positive influence on the health and production in accordance with the interests of environment. Because of low realization of organic food in domestic market and relatively lower living standards, marketing concepts sholud be focused on foreign markets of developed states, where traffic of organic food records significant growth (Prodanovic, 2015).

\section{Customers's Attitudes about Organic Fruits}

Increased sale of organic food, changes in eating habits, concerns for food safety, as well as greater personal health awarness have led to the larger interest of customers for fresh fruits, especially for certified organic fruits (Ferguson, 2004). If there are small children or babies in the house, parents chose to buy organic fruits for reason of concern for food safety. Parents perceive that organic food do not have harmful substances and it is healthy alternative to convential fruits (Smith et al., 2009).

The customers' perception in Australia about organic fruits is improved over time, but there is still difference between customers groups and some customers who are still confused, while some do not understand the concept of organic food. In the UK, there is no difference at all in perception of organic food, at consumers and those who do not buy. Some customers consider that the word "organic" is just a marketing trick (Nguyen, 2013).

Domestic customers are mainly not informed about organic fruits, so they identify it with 
unsprayed and fruits produced on traditional way in gardens and garden plots. Customers are not enough educated and do not know how to recognize organic products. On the other hand, there are customers who consider organic production as fashionable phenomenon and do not have confidence in its integrity (Berenji et al., 2013).

Using a mail survey in Victoria Lea and Vorslei (2005), found that the majority of respondents praise the taste of organic fruits and higher content of vitamins and minerals (Chang, Zepeda, 2005).

Customers of organic fruits largely value the health safety, positive impact on health, respectively. Also, consumers regard $(83.7 \%)$ that organic fruits are much healthier than produced in the conventional way. $79.6 \%$ customers believe that organic fruits are richer in vitamins and minerals (Chart 1).

Chart 1. Organic fruits are richer in minerals and vitamins - answers of respondents (\%)

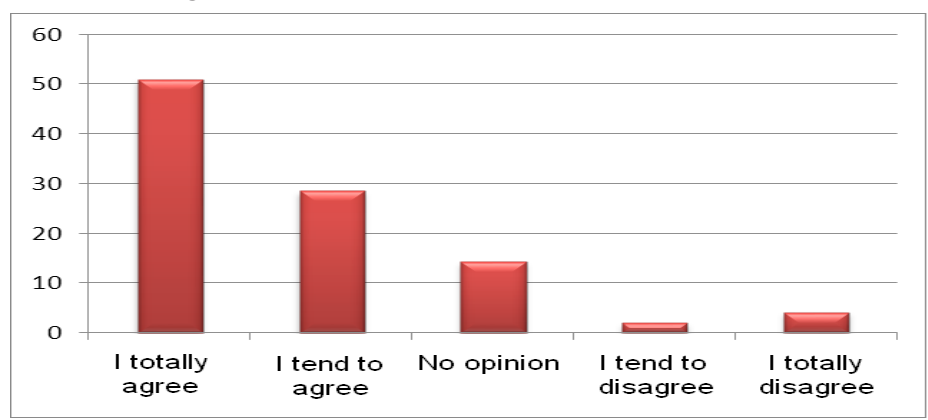

Source: Authors' research

Participants suggest that they rarely buy organic fruits, even $44.9 \%$ of them, while $34.7 \%$ are occasional customers. The number of those who frequently buy organic food is $12.2 \%$, and $3.4 \%$ permanent consumers. $4.8 \%$ of them have never bought organic fruit.

Chart 2. Frequency of purchase of organic food

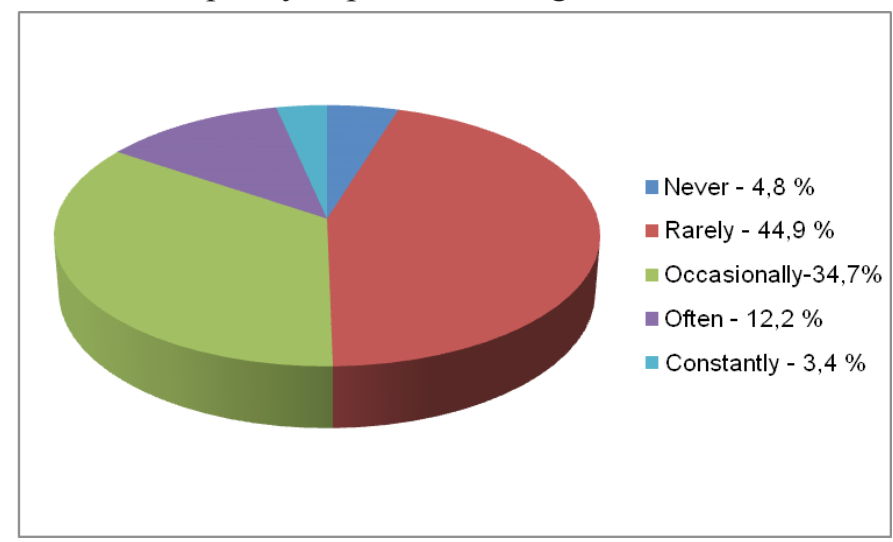

Source: Authors' research 
Results show that customers are informed about organic products and they declaratively support. In the study of Vlahovic et al. (2011), it is suggested that even $70 \%$ of examinees know what organic food is, while $20 \%$ of them have never heard for organic products. It could be concluded that informing the customers about organic food is at high level.

\section{Profile of Customers of Organic Fruits}

Most studies show that those who approach to the organic market are highly educated, have relatively high incomes, live in cities and are concerned about their health. In USA, many organic customers are parents of small children and infants and that characteristic is considered as the reason for growth of organic food market (Lockie et al., 2004).

According to research market which is conducted by $\mathrm{NASO}^{5}$, description of average customer of organic products in Serbia is: woman aged 25-40, educated and aware of the influence of insecure food on health. By buying for her family, she promotes organic food on micro market (Kalentic et al., 2014).

On the basis of research, we defined the profile of organic fruits customers: Organic fruits buys employed person by good financial conditions with children, higher or highly educated, ages between 30 and 50, with a place of residence in the city. This person is likely to be women, but also men are those who buy organic fruits.

\section{Demand's Factors of Organic Fruits}

Demand for organic fruits is larger in regard to the offer, observed at the gobal level, and it is in a steady upward trend. There is a demand in the domestic organic food market, but in a small volume.

Demand for organic fruits is determined by usefulness, the absence of chemical, environmental protetction and better taste, while the appearance of the food, simplicity of preparation and suitability for maintaining a normal body weight are of less importance (Schifferstein, Ophuist, 1998).

Personal health problems are the most important motive for purchase of organic food among the Australian customers, but also those in other countries (Nguyen, 2013).

Misunderstanding of existing certification schemes for organic producers and processors, is one of the factors that confuses customers and turns away from organic products purchase. There are labels, trademarks and logos (Chang, Zepeda, 2005).

Empirical analysis of demand for organic fruits is restricted and mainly focused on the factors research which predominantly influence on making decisions about purchase. We have been exploring how much customers are voluntary to pay higher price for organic food, and how the socioeconomic and demographic factors affect the demand. We have polled the customers personally and electronically, and have processed collected data in order to perceive the attitudes about organic fruits, buying habits and the most significant motives for purchase.

5 NationalAssociationSerbiaOrganica.

EP 2017 (64) 1 (141-155) 
Customer Panel, which we set in two stores of organic food (My Farm and Organic House) also at the market-place of organic products (My Farm) in Novi Sad, in combination with electronic questionnaire, which included several cities in Serbia, gives the answer to the question what the most significant motives for organic fruits purchase are.

Chart 3. Impact of some factors on organic fruits purchase (in \%)

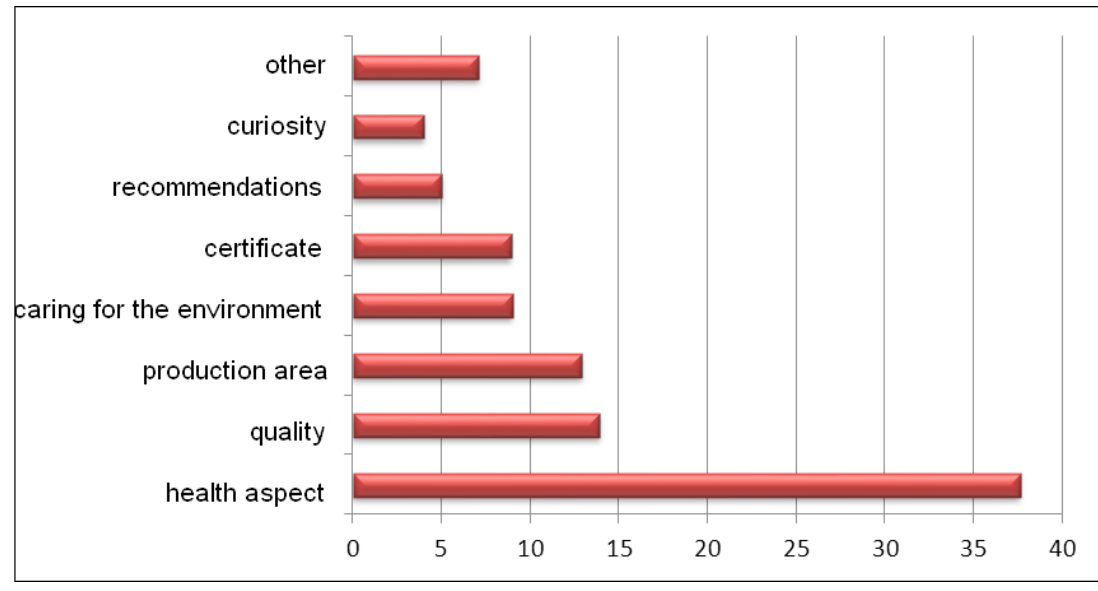

Source: Authors's research

Health aspect is one of the most important reasons for which the customers decide on purchase of organic fruits. In research of Peck et al. (2006), it is suggested that organic apple has more antioxidants, which gives power to the argument that there is potential positive influence on health.

For motives of purchase, health safety of product has the largest effect among the customers, positive impact on health, respectively. Even $77.6 \%$ declared the health aspect as a reason for purchase. With $38.3 \%$ share, health aspect is the most relevant purchase motive (Chart 3 ). Customers accentuate the significance of food and proper nutrition for their health. $46.9 \%$ of them say that proper nutrition is especially significant and they connect organic fruits with it. Younger participants claim that they buy organic fruits for children, especially for babies.

Vlahovic et al. (2011) suggest that $16 \%$ of participants are motivated for purchase of organic products by health care. In our study, the percent is much higher, which can be explained by the fact that customers are gradually changing the consciousness about their health.

Out of total number of respodents, $38.6 \%$ of them claimed, beside other factors, the quality of organic fruits, as the purchase motive. According to impact on making decision about purchase, the quality is on the second place with $13.9 \%$ of share. It is expectable for this factor to be more stronger as purchase motive by the growth of living standards.

In study of Vlahovic et al. (2011), the quality as purchase motive is dominant. Even $35 \%$ of participants declare that the quality is a reason why they decided to buy organic product. 
The customers decide for buying organic fruits also due to they believe that it contains more nutrients than conventional fruits. Huge number of people who have tasted organic fruits are potential customers. When they gradually realise the significance which organic food has, then they will more often begin to buy (Nguyen, 2013).

The studies showed that mistrust in the authenticity of organic products from imports is present almost in all countries of EU. The case of Switzerland is the most noticeable, where main domestic organic label forbid organic products that are transported by plane. Customers in Australia said that they very prefer domestic organic products (preferably purchase directly in farm) and value only organic products from imports, which cannot be produced in country. If the import of organic products is necessary, products originating from surrounding lands are accepted. Also, customers in Japan and USA have a huge preference for locally grown organic products. In order to successfully introduce itself, imported organic products on that markets require specfic marketing efforts, for getting confidience of customers. The United Kingdom and Belgium are two examples where the difference in confidence among domestic and imported organic products is relatively small. This is explained by the fact that domestic organic production in these countries is not capable to catch up with increasing demand, so import is ordinary practice (FAO, 2001).

For $31.67 \%$ of customers who buy organic apples in USA (Vermont), dominant motive for buying is the location or place of production (Wang, Junjie, 2003).

In study of Vlahovic et al. (2011), it is suggested that $40 \%$ of respodents prefer organic products of domestic production, while quarter of respodents prefer foreign organic products. Smaller number of them $(10 \%)$ do not discern between domestic and imported organic food products.

In our study, $26.5 \%$ of respodents declare the origin of product, respectively the area of production, as one of the motive for purchase of organic food. In the same way, they have more confidence in organic fruits produced in country than those from imports.

Therefore, area of production is a significant factor which influence on making decision about organic fruits purchase. With share of $12.9 \%$ this factor gains significant the third place.

The customers suggest that they are aware of fact that conventional food producation has negative effects on environment. Thus, substantial part of them chose organic food purchase, thanks to ecological knowledge. Especially, that are customers with higher or high professional qualifications, while customers with lower education do not suggest this factor as buying motive.

In researches of buying motive of organic fruits, $18.4 \%$ of respodents declare a certificate as one of the motives for purchase. It became a rule that retailers, in their business premises, hold a copy of the certification of producers from who they procure organic products. In such a way, if the buyer is in doubt or does not believe in authenticity of the product, the seller will display a certification. With share of $8.9 \%$ of total purchase motive of organic fruits, we can infer that the certificate gives confidence to customers. 
Regardless of that the sertification and control of organic production do not operate in best way in practice, certificate guarantee in certain degree that the product is produced according to the Law on organic production and associated regulations. During visit familiy Slavnić from Srbobran, we revealed that the supervision is performed once per year, which leaves a space for potential manipulation and misapplications in production. For the time being, everything at us is left to the conscience of manufacturer, will they respect the principles and standards of organic production.

From the other purchase motives, we highlight recommendation, appearance and taste of product, curiosity, packaging, availability and price.

Thanks to recommendation, $10.2 \%$ of respodents bought organic fruits. Also, in our study, recommendation is considered to be golden rule of sales. Of all buying motives, recommendation participates with $5 \%$.

Most customers will say that organic apple is more delicious than those from conventional production, but appearance does not give much confidence, especially for buyers who just sholud make decision. Organic apple is smaller, sometimes stunted, less aesthetic receptive and easily recognisable.

Nice and aesthetically attractive packaging attracts attention of potential customer. Organic products, nicely and practical packed in biodegradable packaging, are placed on the market, and the example is a fresh organic apple on saucer wrapped with foil.

\section{Limiting Factors of Organic Fruits Demand}

Among all respodents, $28.5 \%$ of them, beside the other resons, suggested the price as factor of which they do not buy organic fruits. Beside the price, the mistrust, unavailability in retail, disinterest and low income dominantly affect the customers not to buy organic fruits.

Chart 4. Limiting factors of organic fruits purchase

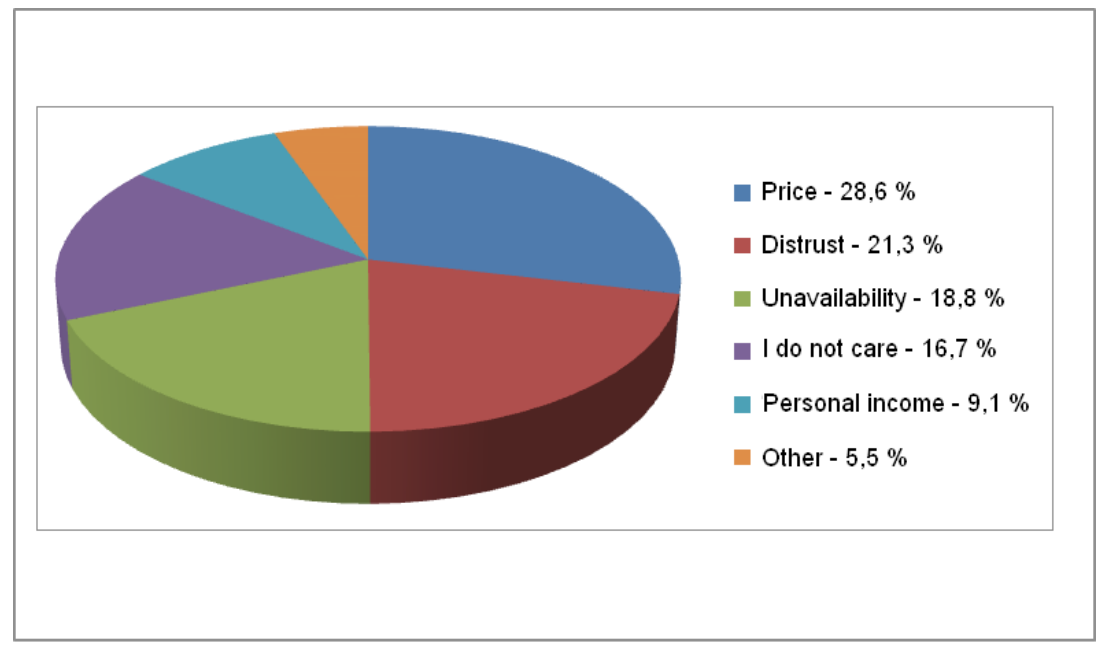

Source: Authors's research 
The research show that customers are mainly determined to pay higher price for organic fruits, but as the price is higher, they are less willing for it.

The prices of organic products vary due to seasonal trends in production and consumption during the time an by location, and on average, they are larger by 20 to $40 \%$ compared to conventional products (Ferguson, 2004).

In one study, $73 \%$ of customers in USA consider that organic food is too expensive (Carloyn, Oberholtzer, 2009).

The price of organic apple in stores of organic food ranges from 160 to 270 dinars, which is 2 to 3 times higher price than the price of conventional apples. The price of organic fruits is too high for most customers.

Customers' confidence is a key item for success in the market of organic products. Credible certification and labeling are important for customer, so he could be able to diferentiate authentic organic products (Sudarevic, 2007).

Research was conducted in Western Australia, on the basis of which only $50 \%$ of participants believe that organic fruits is not chemically treated. A few years later, $89 \%$ of customers believe that pesticides are not applied in organic production. Customers more and more believe that organic food is healthier and better for environment than conventional (Bat, Giblett, 1999).

$26 \%$ of respodents have confidence in domestic organic products, which is not good indicator for further development of market (Vlahovic et al., 2011).

In our study, $36.7 \%$ of respodents claim that they do not believe in organic fruits, of those who do not believe that organic food is produced in our country to those who do not believe in the concept of organic production. They consider that the whole concept of organic food production is placed from some marketing, economic and other reasons.

Establishing the confidence is of vital significance for organic producers and traders and the key conditionod advancement of production and traffic.

When it is about supplying the market by organic products, almost the half of respodents say that it is hardly to find them and there are no in stores (Vlahovic et al., 2011).

Customers assert that beside good will to buy organic fruits, there are not organic fruits in retail. Thus, $42.9 \%$ of respodents said as one of the reasons why they do not buy organic fruits because there is no in sale.

Income of customers defines their behaviour during the purchase. The average net income of employed in Serbia in April 2016 amounted 49.249,00 dinars or 400 euros (RZS). Comparing with developed countires, this number is significantly lower, while the prices of organic food are approximately at the same level or slightly higher in developed countries. Average income of employed in the EU is bigger by 3 to 4 times compared to Serbia. Low income forces customers to buy food with lower prices as conventional. 
In our research, $22.2 \%$ of customers do not buy organic fruits beacuse of low income. Low income has significant share with $9.1 \%$, in structure of factors for which the customers do not buy organic fruits. Economic theory and practice show that customers are more likely to buy more expensive and more quality products, by growing living standards, growing real income, respectively. The growth of demand for organic fruits colud be expected, if the income of customer was increased.

Regarding to organic fruits is more expensive than conventional, it is quite logical that marketing aactivities sholud be directed to customers with bigger incomes. In that context, it is needed to engage on exploring the market of developed countries, where the customers have posibility to afford themselves beside the quantity and quality, too (Matovic, Begovic, 2011).

\section{Conclusion}

In Serbia, potential for development of organic fruits market exists. It is necessary to define organic fruits production as strategic, influence in order to exploit comparative advantages in this production, in order to develop it, and by that market also, to achieve higher economic effects and to preserve resources on which production is based.

The organic food market in Serbia is in initial stage of development, it requires level of investment, both in development of the products itself and promotional activities and education of customers.

In order to increase demand for organic fruits, it is necessary to influence on changing mind of customers and establish confidence in organic products and whole system of organic production.

There are a lot of motives for organic fruits purchase, but significant of each is varied among the countries and customers' groups and probably it is being changed over the time. Motives directly related to customers (quality, health safety/ positive impact on health and taste) are more important than others (environment, ethics). This is in agreement with research of Shepher et al. (2005), who suggest the main reasons for choice both, fresh and processed organic food, that it is healthier, with better quality, including better taste.

It is expected that increasing interest for organic fruits will condition the development of market and expansion of traffic flows of organic fruits. Sustainability and further development of organic fruits production is determined by market, or demand, respectively.

\section{Literature}

1. Batt, P. J., Giblett, M. (1999): A pilot study of consumer attitudes to organic fresh fruit and vegetables in Western Australia, Food Australia, Vol. 51, No. 11, pp. 549-550, Australian Institute of Food Science \& Technology,North Sydney, Australia, (available on: http:// eurekamag.com/research/014/894/014894262.php).

2. Berenji, J., Milenković, S., Kalentić, M., Stefanović E. (2013): Nacionalna istraživačka agenda za sector organske proizvodnje. Nacionalna asocijacija“'Serbia Organica”, 
Beograd, Srbija.

3. Chang, H. S., Zepeda, L. (2005):Consumer perceptions and demand for organic food in Australia: Focus group discussions, Renewable Agriculture and Food Systems, Vol. 20, No. 3, pp. 155-167, Cambridge University Press,Cambridge, UK.

4. Carolyn, D. and Oberholtzer,L. (2009):Marketing U.S. Organic Foods: Recent Trends From Farms to Consumers, Economic Information Bulletin No. 58. U.S. Dept. of Agriculture, Economic Research Service.

5. FAO (2001):World Markets for Organic Fruit and Vegetables - Opportunities for Developing Countries in the Production and Export of Organic Horticultural Products. International Trade Centre Technical Centre or Agricultural and Rural Cooperation Food and Agriculture Organization of the United Nations. Rome. (Dostupno na: http://www.fao. org/docrep/004/y1669e/y1669e06.htm\#bm06)

6. Peck, G. M., Andrews, P. K., Reganold, J. P., Fellman,J. K. (2006):Apple Orchard Productivity and Fruit Quality under Organic, Conventional, and Integrated Management, Hort Science, Vol. 41, No. 1, pp. 99-107.

7. Ferguson,J. J. (2004):World Markets for Organic Fruits and Vegetables, Institute of Food and Agricultural Sciences, University of Florida.

8. Kalentić, M., Stefanović, E., Simić, I., Marz, U. (2014):Organska poljoprivreda u Srbiji 2014, Nacionalno udruženje za razvoj organske proizvodnje „Serbia organica“, Beograd, Srbija.

9. Kuzman, B., Stegić, M., Subić, J. (2016): Market Oriented Approach of Revealed Comparative Advantage in International Trade, Economics of Agriculture, Vol. 63, No. 1, pp. 247-260, Institute of Agricultural Economics, Belgrade, Serbia.

10. Lockie, S., Lyons, K., Lawrence, G., Grice, J. (2004):Choosing organics: a path analysis offactors underlying the selection of organic food among Australian consumers, Appetite, Vol. 43, pp. 135-146.

11. Matović, G., Begović, N. (2011):Poslovniplan: Povećanje konkurentnosti kompanija za preradu voća i povrća kroz umrežavanje. Udruženje prerađivača voća i povrća, Kraljevo, Srbija.

12. Marz, U., Kalentić, M., Stefanović, E., Simić, I. (2013):Organska poljoprivreda u Srbiji, Nacionalno udruženje za razvoj organske proizvodnje „Serbia organica“, Beograd, Srbija.

13. Milenković, S., Kalentić, M., Stefanović, E., Milenković, A. (2011): Vodič za organsku proizvodnju jabuke. Nacionalna asocijacija“Serbia organica”, Beograd, Srbija.

14. Mitić, S., Gligorijević, M. (2012):Globalni izazovi i perspective marketinga proizvoda zdrave hrane,Marketing, vol. 43, no. 3, pp. 205-218,SeMA - Srpsko udruženje za Marketing - Ekonomski fakultet u Beogradu, Beograd, Srbija.

15. Nguyen P.T. (2013):Consumers' perceptions of organic food in Australia and other countries: A review, Journal of Agricultural Economics and Development, Vol. 2, No. 2, pp. 44-54.

16. Prodanović, R. (2015):Uticaj relevantnih faktora na proizvodnju, preradu i promet 
organskog voća, doktorska disertacija, Fakultet za ekonomiju i inženjerski menadžment, Univerzitet Privredna akademija, Novi Sad, Srbija.

17. Wang, Q. and Junjie, S. (2003):Consumer preference and demand for organic food: Evidence from a Vermont survey, American Agricultural Economics Association Annual Meeting Montreal, Canada.

18. Rakić, B., Rakić,M. (2009): Upravljanje marketingom organske hrane, Ekonomika poljoprivrede, vol. 56, no. 3, pp. 453-468, Institut za ekonomiku poljoprivrede, Beograd, Srbija.

19. Republički zavod za statistiku (RZS), (14 Mart, 2016), (http://webrzs.stat.gov.rs)

20. Richter, T. and Padel, S. (2007):The European market for organic food. The World of Organic Agriculture-Statistics and Emerging Trends 2007, pp. 143-154.

21. Schifferstein, H. and Ophuist, P. (1998): "Healthrelated determinants of organic food consumption in the Netherlands”, Food Quality and Preference, Vol. 9,No. 3, pp. 119133.

22. Shepherd, R., Magnusson, M.K., Sjoden, P.O. (2005):Determinants of consumer behavior related to organic foods, AMBIO: A Journal of the Human Environment, Vol. 34, No. 4, pp. 352-359.

23. Smith, T. A., Huang, C. L., and Lin, B.H. (2009): Does Price or Income Affect Organic Choice? Analysis of U.S. Fresh Produce Users, Journal of Agricultural and Applied Economics, Vol. 41, No. 3, pp. 731-744.

24. Sudarević, T. (2007):Ekonomski faktori i marketing aktivnosti u razvoju organske poljoprivredne proizvodnje u Srbiji, Centar za organsku proizvodnju Zdravo Organic, Selenča, Srbija.(Dostupno na:

http://organiccentar.rs/sites/default/files/radovi sa foruma/Skripta.pdf)

25. Vlahović, B., Radojević, V., Živanić, I. (2011):Istraživanje stavova potrošača o potrošnji organske hrane u Srbiji. Ekonomika poljoprivrede, vol. 58, br. 3,str. 441-456, Institut za ekonomiku poljoprivrede, Beograd, Srbija.

26. Willer, H. and Lernoud, J., (Eds.) (2016). The World of Organic Agriculture. Statistics \& Emerging Trends 2016., Research Institute of Organic Agriculture (FiBL), Frick and IFOAM - Organics International, Bonn. 


\section{TRŽIŠTE I PROMET ORGANSKOG VOĆA U SRBIJI}

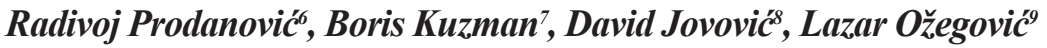

\section{Rezime}

Cilj rada je da se istraži tržište i promet organskog voća, odnosno faktori koji determinišu tražnju, stavov i kupaca i njihovi motivi za kupovinu.

Od metoda koji se primenjuju ključni su anketni upitnik i intervju, a koristi se statistički, grafički i logički metod.

Tržište organskog voća u Srbiji počelo se razvijati poslednjih godina, postoji tražnja, aliumalomobimu.Održivost $i$ dalji razvoj organske voćarske proizvodnje u velikoj meri uslovljen je tražnjom.

Organsko voće kupuje zaposlena žena dobrog materijalnog stanja sa decom, višeg ili visokog obrazovanja, starosti između 30 i 50 godina, sa mestom stanovanja u gradu.

Zdrastvenabezbednost, kvalitet, područje proizvodnje i briga za životnu sredinu najvažniji su motivi za kupovinu organskog voća. Sertifikat, preporuka, izgled i ukus proizvoda, znatiželja i pakovanje su od sekundarnog značaja.

Ključni faktori zbog kojih potrošači ne kupuju organsko voće su nedostupnost u kanalima prodaje, visoka cena, nepoverenje u organski proizvod i nizak dohodak.

Ključne reči: tržište, promet, tražnja, organsko voće, Srbija.

6 Docent, dr Radivoj Prodanović, Univerzitet Privredna akademija u Novom Sadu, Fakultet za ekonomiju i inženjerski menadžment u Novom Sadu, Cvećarska Ulica br. 2, 21000 Novi Sad, Srbija, Telefon: +381 21400 484, E-mail: rprodanovic@fimek.edu.rs

7 Vanredni profesor, dr Boris Kuzman, Institut za ekonomiku poljoprivrede, Volgina Ulica br. 15, 11060 Beograd, Srbija, Telefon: +381 63590 129, E-mail: kuzmanboris@yahoo.com

8 Vanredni profesor, dr David Jovović, UniverzitetuPrištini, Poljoprivrednifakultet, 38219 Lešak, Telefon: +3812888 261, E-mail: david.jovovic@pr.ac.rs

9 Vanredni profesor, dr Lazar Ožegović, Univerzitet Privredna akademija u Novom Sadu, Fakultet za ekonomiju i inženjerski menadžment u Novom Sadu, Cvećarska Ulica br. 2, 21000 Novi Sad, Srbija, Telefon: +381 21400 484, E-mail: ozegovic.lazar@gmail.com

EP 2017 (64) 1 (141-155) 
ECONOMICS OF

AGRICULTURE

\section{CONTENT}

1. Željko Anđelković, Aleksandra Dragin, Sanja Božić, Kristina Košić

EMOTIONAL EXHAUSTION AND JOB SATISFACTION OF TOUR GUIDES IN RURAL AREAS . . . . . . . . . . . . . . 11

2. Sanja Đukić, Danica Glavaš-Trbić, Nikola Banjac

MANAGEMENT PROBLEMS OF RURAL DEVELOPMENT IN FRUŠKA GORA . . . . . . . . . . . . . . . . . . . . 27

3. Ivana Ilić, Bojan Krstić, Sonja Jovanović

ENVIRONMENTAL PERFORMANCES OF AGRICULTURE IN THE EUROPEAN UNION COUNTRIES . . . . . . . . . . . . . 41

4. Nataša Kljajić, Jonel Subić, Zorica Sredojević

PROFITABILITY OF RASPBERRY PRODUCTION

ON HOLDINGS IN THE TERRITORY OF ARILJE. . . . . . . . . . . 57

5. Aleksandar Maksimović, Zoran Grgić, Ferhat Ćejvanović

MULTI-ATTRIBUTE ANALYSIS OF ORCHARD ACCORDING

TO THE INTEGRATED PRODUCTION CONCEPT . . . . . . . . . . 69

6. Ozrislava Milinković, Branislav Jakić, Slobodan Vuksanović,

Dragana Macura, Milica Šelmić

MULTI- CRITERIA DECISION BASED APPROACH

TO SELECTING THE TYPE OF INDUSTRIAL HALLS

USED IN FOOD INDUSTRY $\ldots \ldots \ldots \ldots$. . . . . . . . . . 81

7. Gordana Nikić, Ljubiša Stamatović, Azra Sućeska

EMOTIONAL COMPETENCIES AND PERSONALITY

TRAITS OF MANAGERS IN MODERN AGROBUSINESS. . . . . . . .97

8. Vladimir Obradović, Nemanja Karapavlović

FINANCIAL REPORTING OF COMPREHENSIVE INCOME

IN THE FOOD AND BEVERAGE SECTOR

IN THE REPUBLIC OF SERBIA . . . . . . . . . . . . . . 113 
9. Aleksandar Ostojić, Nebojša Savić, Željko Vaško

CONSUMER ATTITUDES

ON BUYING FISH IN BANJA LUKA . . . . . . . . . . . . . . . 129

10. Radivoj Prodanović, Boris Kuzman, David Jovović, Lazar Ozegović

MARKET AND TRADE OF ORGANIC FRUITS IN SERBIA $\ldots . . .141$

11. Predrag Vukadinović, Aleksandar Damnjanović, Ljiljana Dimitrijević

ANALYSIS OF THE SALES AND INCOMES BETWEEN

DIFFERENT CATEGORIES OF AGRICULTURAL PRODUCTS . . . 157

12. Jugoslav Aničić, Svetlana Vukotić, Goran Maksimović

THE POSSIBILITIES AND LIMITATIONS

OF ENTREPRENEURSHIP DEVELOPMENT

IN AGRICULTURE IN SERBIA . . . . . . . . . . . . . . 171

13. Željko Bjelajac, Marijana Dukić - Mijatović, Joko Dragojlović

FOOD SAFETY AS ONE OF THE MAIN SAFETY $P$

REOCCUPATIONS OF A MODERN MAN . . . . . . . . . . . . . 191

14. Milan Bradić, Ljiljana Kosar, Lukrecija Djeri, Svetlana Vukosav, Vuk Garača

ECO-LABELLING OF ACCOMMODATION FACILITIES

AND ITS PERCEPTION BY RURAL TOURISTS:

CASE STUDY OF VOJVODINA . . . . . . . . . . . . . . 205

15. Vaso Jegdić, Iva Škrbić, Srđan Milošević

MODELS OF ENTREPRENURSHIP DEVELOPMENT

IN RURAL TOURISM DESTINATIONS IN VOJVODINA . . . . . . . 221

16. Duško Kuzović

MUSEUM OF VERNACULAR ARCHITECTURE OF WESTERN SERBIA

- Representative curtilages of the area surrounding middle

course of the river Drina and Podgorina . . . . . . . . . . . 239

17. Branko Mihailović, Zoran Simonović, Nikola Ćurčić

AGRICULTURAL RESOURCES AND DEVELOPMENT

PRIORITIES OF THE MUNICIPALITY OF STARA PAZOVA. . . . . 259

18. Radmilo Nikolić, Aleksandra Fedajev, Vidoje Stefanović, Silvana Ilić

THE AGRICULTURE SECTOR IN WESTERN BALKANS

- SOME CHARACTERISTICS OF DEVELOPMENT. . . . . . . . . . 275

19. Vladimir Njegomir, Rajko Tepavac, Nenad Ivanišević

ALTERNATIVE SOURCES OF FINANCING

ENTREPRENEURIAL UNDERTAKINGS IN AGRICULTURE . . . 295

Economics of Agriculture, Year 64, No. 1 (1-404) 2017, Belgrade 
20. Daniela Nuševa, Kristina Mijić, Dejan Jakšić

THE PERFORMANCES OF COFFEE PROCESSORS

AND COFFEE MARKET IN THE REPUBLIC OF SERBIA . . . . . . 307

21. Svetlana Roljević Nikolić, Predrag Vuković, Biljana Grujić

MEASURES TO SUPPORT THE DEVELOPMENT OF ORGANIC

FARMING IN THE EU AND SERBIA . . . . . . . . . . . . 323

22. ŽeljkoVojinović, Vera Zelenović, DragoCvijanović

PROGRAM OF STATE SUPPORT

TO AGRICULTURAL CREDITING. . . . . . . . . . . . . . . . 339

23. Nikola Vuksanović, Dragan Tešanović, Bojana Kalenjuk,

Milijanko Portić, Marija Knežević

SOCIO-DEMOGRAPHIC CHARACTERISTICS

AS DETERMINANTS OF DIFFERENCES

IN PERCEPTION OF LOCAL GASTRONOMY . . . . . . . . . . . . 359 